\title{
Relation between recruitment, sea surface temperature, and density-independent mortality of the Pacific sardine (Sardinops caeruleus) off the southwest coast of the Baja California Peninsula, Mexico*
}

\author{
ENRIQUE MORALES-BOJÓRQUEZ1, VÍCTOR MANUEL GÓMEZ-MUÑOZ², \\ ROBERTO FÉLIX-URAGA² and REYNA MARÍA ALVARADO-CASTILLO ${ }^{\dagger}{ }^{2}$
}

${ }^{1}$ Instituto Nacional de la Pesca, Laboratorio de Dinámica de Poblaciones del Pacífico Norte, CRIP La Paz. Carretera a Pichilingue km 1, s/n. CP 23020, La Paz, Baja California Sur, México. E-mail: embojorq@ipn.mx ${ }^{2}$ Centro Interdisciplinario de Ciencias Marinas. Av. Instituto Politécnico Nacional s/n. CP 23000. La Paz, Baja California Sur, México.

\begin{abstract}
SUMMARY: The density-independent mortality, considered in the stock-recruitment model of Ricker, was related to the interannual variability of the sea surface temperature (SST) during 1981 to 1993 in Bahía Magdalena, Baja California Sur and Isla Cedros, Baja California, Mexico. From the stock-recruitment curve fitted to the observed data the variation in the density-independent mortality was estimated, maintaining fixed the value of the density-dependent coefficient. The density-independent parameters estimated in this way were related to the SST by using a functional relationship that considers six principal components. This function permitted identification of the changes of the density-independent mortality and its relation to the recruitment of the Pacific sardine Sardinops caeruleus. We determined density-independent mortality greater than 3.38 as years with recruitment greater than $25,000 \mathrm{t}$, and density-independent mortality less than 3.38 as years with recruitment less than $15,000 \mathrm{t}$. The seasons of greatest influence on the density-independent mortality in relation to the SST were autumn, winter and spring in both regions (Bahía Magdalena and Isla Cedros). In these seasons when the SST $>19.3^{\circ} \mathrm{C}$ (warmer waters) the variations in recruitment of Pacific sardine were observed.
\end{abstract}

Key words: sea surface temperature, recruitment, density-independent mortality, Pacific sardine.

RESUMEN: RELACIÓN ENTRE EL RECLUTAMIENTO, LA TEMPERATURA SUPERFICIAL DEL MAR Y LA MORTALIDAD DENSO INDEPENDIENTE DE LA SARDINA DEL PACífICO (SARDINOPS CAERULEUS) DE LA COSTA SUROESTE DE LA PENÍNSULA DE BAJA CALIFORNIA, MÉXICO. - La mortalidad denso independiente considerada en el modelo de stock reclutamiento de Ricker fue relacionada con la variabilidad interanual de la temperatura superficial del mar (TSM), durante el periodo de 1981 a 1993 en Bahía Magdalena, Baja California Sur e Isla Cedros, Baja California, México. Ajustando la curva stock reclutamiento a los datos observados, se estimó la variación de la mortalidad denso independiente, manteniendo constante el valor del coeficiente de mortalidad denso dependiente. Los parámetros de denso independencia estimados de ésta forma, fueron relacionados con la TSM usando una relación funcional que considera seis componentes principales. Esta función permitió identificar los cambios en la mortalidad denso independiente y su relación con el reclutamiento de la sardina del pacífico Sardinops caeruleus. Se determinó una mortalidad denso independiente $>3.38$ como años con reclutamiento $>25,000 \mathrm{t}$, y mortalidad denso independiente $<3.38$ como años con reclutamiento $<15,000$ t. Las estaciones de mayor influencia sobre la mortalidad denso independiente en relación a la TSM fueron: otoño, invierno y primavera en ambas regiones (Bahía Magdalena e Isla Cedros). En estas estaciones fueron observadas las variaciones en reclutamiento de la sardina del pacífico cuando la TSM $>19.3^{\circ} \mathrm{C}$ (aguas cálidas).

Palabras clave: temperatura superficial del mar, reclutamiento, mortalidad denso independiente, sardina del Pacífico.

\footnotetext{
*Received November 20, 2000. Accepted July 1, 2002.
} 


\section{INTRODUCTION}

Small pelagic fisheries have high interannual variability of abundance and distribution, and these changes can be related to physical variables of the ocean (Lluch-Belda et al., 1989, 1991, 1992a, b). Analyses of scale counts in anaerobic sediments indicate natural cyclical fluctuations in abundance of sardine and anchovy, apparently caused by the environment alone (Baumgartner et al., 1992). Environmental effects on sardine abundance probably affect early life stages and therefore the magnitude of recruitment (Smith et al., 1992; Cisneros-Mata et al., 1996). Sea surface temperature and upwellings may limit sardine recruitment because upwellings induce advection of larvae into offshore areas where survival is poor. This event may be associated with poor reproductive success (Murphy, 1960; Iles, 1973), because sardine spawnings may tend to be unsuccessful in cold water, because spawning is delayed or because the spawning period is shortened (Marr, 1960).

The principal species of small pelagics in the commercial fishery between Isla Cedros and Bahía Magdalena, Mexico is the Pacific sardine (Sardinops caeruleus Girard 1854) (Fig. 1). The fleet size in the fishing area varies between 5 and 7 boats per year, the fleet is composed of boats with a carrying capacity of between 60 and $120 \mathrm{t}$, and the fishing grounds are mostly located within Bahía Magdalena. Pacific sardine has been harvested commercially along the western coast of Baja California Peninsula since 1951, but when the sardine fishery collapsed in Cal-

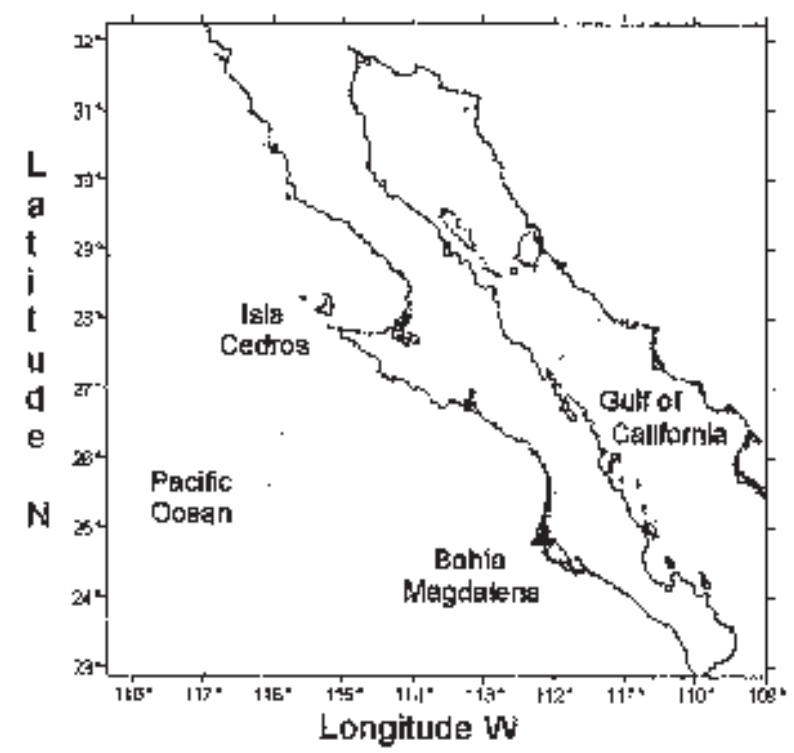

FIG. 1. - Study zone along the southwest coast of the Baja California Peninsula, Mexico. ifornia, the Mexican fishery was established at Isla Cedros (1961) and Bahía Magdalena (1972) (FélixUraga et al., 1996). The fishing season is throughout the year; it has two periods of maximum catches, from late spring to early summer, and from late fall to early winter. $S$. caeruleus has a seasonal reproductive cycle from winter to early summer, and the species shows two spawning periods, the most important peak being observed during January and February, with another small spawning peak during July and August (Torres-Villegas et al., 1995). For the Pacific sardine, a few annual classes are present (Félix-Uraga et al., 1996) and the abundance of the population depends strongly on recruitment. Therefore, the relation between the environment and abundance of the resource is a close one.

Statistical models between recruitment and environment for some exploited populations have been developed by Tang (1985), who proposed in the prawn (Panaeus orientalis) a modification to the stock-recruitment model of Ricker through a multiple linear function associated with the density-independent mortality coefficient. Gardiner and Shachley (1991) showed that sea surface temperature (SST) is related to the size of the stock, growth, and survival of juveniles in a population of salmon (Salmo salar). Clark (1992) and Hannah (1993) used regression models to evaluate the influence of the environmental variability on the recruitment of arctic grayling (Thymallus arcticus) and ocean shrimp (Pandalus jordani). Jacobson and MacCall (1995) analysed models of the stock-recruitment relation for Pacific sardine, taking into account the SST variability, and showing that fluctuations in the recruitment were influenced by the changes in the SST. The relation between environmental factors and sardine population may be affected by other physical regimes such as mixing, upwelling, and thermal stratification processes (Hemingway, 1979; Huato-Soberanis and Lluch-Belda, 1987; Lluch-Belda et al., 1989). In this paper, we investigate the relation between recruitment of Pacific sardine off the southwest coast of Baja California Peninsula, Mexico, and environmental conditions related to the interannual variability of the sea surface temperature.

\section{MATERIAL AND METHODS}

The estimates of the stock size and recruitment for the southern stock of $S$. caeruleus off the southwest coast of the Baja California Peninsula, Mexico 
TABLE 1. - Recruitment and adult stock estimated with VPA (Morales-Bojórquez, 1999).

\begin{tabular}{lcc}
\hline & Recruits (MT) & Adult stock (MT) \\
\hline 1981 & 15,506 & 69,427 \\
1982 & 24,236 & 10,357 \\
1983 & 14,226 & 14,022 \\
1984 & 34,753 & 15,417 \\
1985 & 38,156 & 27,436 \\
1986 & 26,978 & 33,349 \\
1987 & 39,635 & 23,161 \\
1988 & 34,759 & 34,533 \\
1989 & 21,849 & 36,885 \\
1991 & 16,745 & 31,123 \\
1992 & 15,045 & 15,263 \\
1993 & 32,867 & 7,633 \\
& 24,997 & 22,733 \\
\hline
\end{tabular}

during 1981-1993 were obtained through virtual population analysis (VPA) (Pope, 1972). The individuals in the catch from Bahía Magdalena and Isla Cedros were combined in the VPA. Sagittae otoliths were used to estimate age of fish in the catch (FélixUraga et al., 1996). Adult stock and recruitment were estimated with tuned VPA using criteria for effort (Table 1) (Hilborn and Walters, 1992; MoralesBojórquez, 1999). The natural mortality ( $\mathrm{M}=$ 0.6/year) was estimated using the Silliman method (Ricker, 1975). The sea surface temperature was obtained from the Comprehensive Ocean Atmosphere Data Set (COADS) (Roy and Mendelssohn, 1994), $24^{\circ} \mathrm{N}, 113^{\circ} \mathrm{W}$ for Bahía Magdalena (MB), and $27^{\circ} \mathrm{N}, 116^{\circ} \mathrm{W}$ for Isla Cedros (CI) (Fig. 1). We used the monthly average of the SST for each year and each region, building a matrix of 13 years by 24 values of SST.

The VPA was tuned to include auxiliary information into the cohort analysis; the index (I) was CPUE data (Quinn II and Deriso, 1999). In this case, the estimated index at time $t$ denoted as $I_{t}^{E}$ was computed as $I_{t}^{E}=I_{t}^{O}+\varepsilon_{t}$, where $I_{t}^{O}=\delta_{0}+\delta_{1} N_{a, t}$; therefore, $I_{t}^{O}$ represents the observed index at time $t, \delta_{0}$ and $\delta_{1}$ are calibration coefficients, $N_{a, t}$ is number of individuals at age $a$ and time $t$, and $\varepsilon_{t}$ is error term distributed normally with mean and variance of $I_{t}{ }^{O}$. Parameter $\delta_{0}$ is an optional intercept term, which allows an index to be linearly related to abundance $N_{a, t}$ without being directly proportional (Hilborn and Walters, 1992; Quinn II and Deriso, 1999). Given initial estimates of abundance, the tuned abundance and calibration coefficients were estimated by minimising the next objective function:

$$
R S S_{N_{a, t}}=\sum_{I} \sum_{a} \sum_{t} \lambda_{I, a, t}\left(I_{t}^{E}-I_{t}^{O}\right)^{2}
$$

where $R S S_{N_{a, t}}$ is a residual sum of squares between the estimated and observed index. The $\lambda$ value is a ratio of variance (variance of observed logarithm catch $\sum_{a} \sum_{t} N_{a, t}$ divided by the variance of observed logarithm index $I_{t}^{O}$ ); therefore, we consider $\lambda$ to be a weighting factor that adjusts the amount of influence of auxiliary information (Deriso et al., 1985; Quinn II and Deriso, 1999).

\section{Model}

The stock-recruitment model of Ricker (1975) uses a parameter $(\beta)$ related to the density-dependent mortality and one $(\alpha)$ associated with the density-independent natural mortality:

$$
R=\alpha S \exp (-\beta S)
$$

Our approach assumed the density-dependent parameter $\beta$ was an intrinsic characteristic of the stock that was constant from year to year (Harris, 1975; Tang, 1985; Tang et al., 1989). In our analysis, variations in $\alpha$ were related to density-independent effects, like the fluctuations of SST expressed as principal components (Doi, 1973). The parameters $\alpha$ and $\beta$ were estimated using a nonlinear fit (Cisneros-Mata et al., 1995). A nonlinear sum of squares was used, fitting the model to the data with $\log$ transformation of the recruitment data. The log transformation stabilizes the variance of residuals and the objective function was the following (Hilborn and Walters, 1992):

$$
S S Q=\sum_{t=1}^{n}\left(\ln R_{O b s}-\ln R_{E s t}\right)^{2}
$$

where $R_{o b s}=$ observed recruitment, $R_{\text {est }}=$ estimated recruitment, and $t=$ fishing season. Parameters $\alpha$ and $\beta$ were used to build the classical stock-recruitment curve for $S$. caeruleus . Maintaining $\beta$ constant, the theoretical value of the coefficient $\alpha_{t}$ at year $t$ was calculated from the following expression:

$$
\alpha_{t}=R_{t} /\left[S_{t} \exp \left(-\beta S_{t}\right)\right]
$$

The values of $\alpha_{t}$ were related to principal components $\left(\mathrm{Pc}_{\mathrm{i}}\right)$. In this way, the $\alpha_{t}$ coefficient was described by the multiple linear equation (Doi, 1973):

$$
\alpha_{t}=a_{0}+\sum_{i=1}^{m} a_{i} P c_{i}
$$


In the analysis of multiple regression we did not use as independent variables the $S S T$ values, but the values of $P c_{i}$ (as vectors) estimated with multivariate analysis. $P c_{i}$ has the characteristic of being orthogonal and uncorrelated, avoiding the regression on residuals (Mardia et al., 1989; Morrison, 1990; Milstein, 1993). Orthogonality is defined as perfect non-association between variables (Manly, 1994; Krzanowski, 1993). If two or more variables are orthogonal, the correlation between them is zero (Tabachnick and Fidell, 1989).

Each principal component is a linear combination of the physical factors $\left(X_{j}\right)$ :

$$
P c_{i}=\sum_{j} \lambda_{i, j}\left[\left(X_{j}-X_{i}\right) s_{j}^{-1}\right]
$$

where $\lambda_{i j}$ is the eigenvector's $j$-th coordinate of the $i$ th principal component. It therefore represents the contribution of each physical factor $X_{j}$ (with mean $\bar{X}_{j}$ and variance values $s_{j}^{2}$ ) (Pielou, 1984; Tabachnick and Fidell, 1989; Ortega-García and Gómez-Muñoz, 1992). For the $m$ principal components that explain a high percentage of the total variability and are highly correlated with $\alpha_{t}$, we used the following stock recruitment model:

$$
R_{t}=\left[\left(a_{0}+\sum_{i=1}^{m} a_{i} P c_{i}\right) * S_{t}\right] * \exp \left(-\beta S_{t}\right)
$$

Principal Component Analysis permitted a ranking and simplification of the new variables called principal components, determining the total variation of the data, and explaining it with a few factors (factor loadings $\geq 0.7$ ). The criterion used to determine the number of the independent variables $P c_{i}$ in sequential way was the test of confidence statistics of $r^{2}$ of Sokal and Rholf (1981).

\section{RESULTS}

The Ricker model showed values of the mortality coefficients $\alpha=3.38$ and $\beta=-4.19 \times 10^{-5}$. The variations in the estimation of value $\alpha_{t}$ showed the same trends as the observed recruitment for Sardinops caeruleus during each year analysed (Fig. 2). The estimation of $\alpha_{t}$ with the principal components showed that six principal components of a total of 24 computed $\left(r^{2}=0.93, P<0.05\right)$ participated, explaining $91 \%$ of the total variation of the information in terms of variance accumulated (Table 2).

The analysis of the principal components that participated in the model (expression 7) showed the seasons of main statistical importance (factor loadings $\geq 0.7$; Table 2 ). The first principal component had a contribution of $42.28 \%$ of variance, where October, November, and December (autumn) in $\mathrm{MB}$, and November, and December (autumn) in CI were months with $\mathrm{SST}>23.4^{\circ} \mathrm{C}$ in $\mathrm{MB}$, and $\mathrm{SST}>20.8^{\circ} \mathrm{C}$ in CI. In the second principal component (with variance of $19.9 \%$ ) January, February, and March (winter) in MB, and January, and February (winter) in CI were identified as months with $\mathrm{SST}>21.7^{\circ} \mathrm{C}$ in $\mathrm{MB}$, and $\mathrm{SST}>$ $19.3^{\circ} \mathrm{C}$ in CI. Finally, the third principal compo-

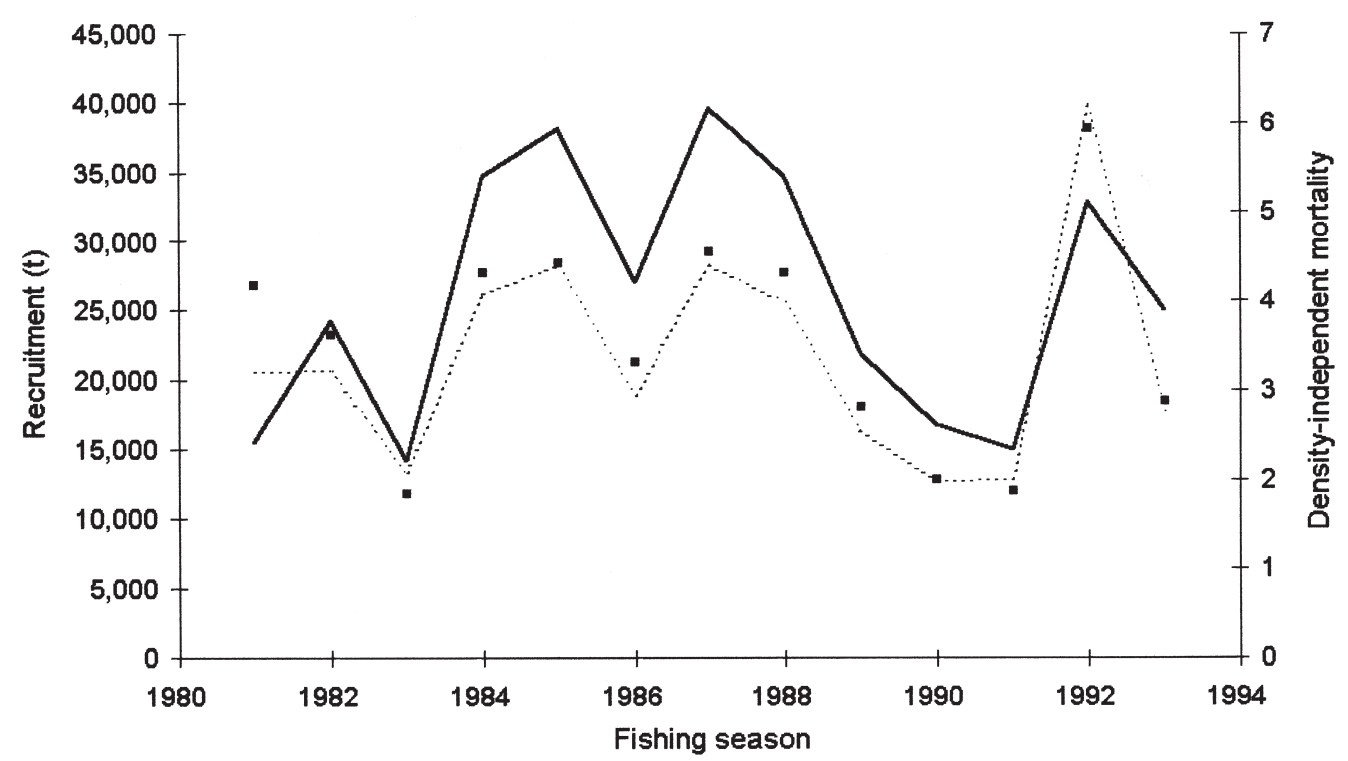

FIG. 2. - Interannual variations of the density-independent mortality observed (filled squares), estimated density-independent mortality (dotted line), and recruitment (solid line). 
TABLE 2. - Eigenvectors (Eigv) estimated with principal components with confidence level $P<0.05$. Only the eigenvectors of the principal components that were used in the multiple linear model as independent variables are shown. The first column has the key: JAN $=\mathrm{January}$, T $=\mathrm{SST}, \mathrm{MB}=$ Bahía Magdalena and CI = Isla Cedros. Eig. = Eigenvalue, Var. = Variance $(\%)$, Varac. = Variance accumulated $(\%)$.

\begin{tabular}{|c|c|c|c|c|c|c|}
\hline & Eigv 1 & Eigv 2 & Eigv 3 & Eigv 4 & Eigv 5 & Eigv 6 \\
\hline JANTMB & -0.05 & 0.95 & 0.06 & 0.07 & 0.02 & -0.03 \\
\hline FEBTMB & -0.09 & 0.94 & -0.20 & -0.02 & -0.08 & 0.00 \\
\hline MARTMB & 0.00 & 0.82 & 0.18 & 0.10 & 0.12 & 0.49 \\
\hline APRTMB & -0.04 & 0.40 & 0.70 & 0.36 & 0.28 & 0.13 \\
\hline MAYTMB & 0.15 & 0.37 & 0.73 & 0.42 & 0.20 & 0.07 \\
\hline JUNTMB & 0.27 & 0.32 & 0.45 & 0.57 & 0.14 & 0.13 \\
\hline JULTMB & 0.28 & 0.10 & 0.57 & 0.65 & -0.02 & -0.05 \\
\hline AUGTMB & 0.28 & 0.09 & 0.32 & 0.86 & 0.15 & 0.01 \\
\hline SEPTMB & 0.46 & -0.08 & 0.13 & 0.82 & 0.05 & -0.02 \\
\hline OCTTMB & 0.76 & 0.04 & -0.10 & 0.28 & -0.17 & 0.07 \\
\hline NOVTMB & 0.88 & 0.10 & 0.05 & 0.37 & 0.05 & 0.03 \\
\hline DECTMB & 0.92 & 0.15 & 0.09 & 0.20 & 0.16 & -0.01 \\
\hline JANTCI & 0.12 & 0.89 & 0.09 & 0.28 & 0.00 & -0.04 \\
\hline FEBTCI & 0.13 & 0.89 & 0.23 & 0.09 & 0.01 & -0.06 \\
\hline MARTCI & -0.07 & 0.50 & 0.76 & -0.07 & 0.26 & -0.02 \\
\hline APRTCI & 0.09 & -0.13 & 0.95 & 0.10 & 0.08 & -0.04 \\
\hline MAYTCI & 0.16 & -0.03 & 0.90 & 0.23 & 0.06 & 0.04 \\
\hline JUNTCI & 0.07 & -0.05 & 0.73 & 0.17 & -0.13 & 0.02 \\
\hline JULTCI & -0.12 & 0.04 & 0.52 & 0.39 & -0.03 & 0.01 \\
\hline AUGTCI & 0.28 & -0.01 & 0.41 & 0.42 & 0.75 & 0.04 \\
\hline SEPTCI & 0.27 & 0.29 & 0.19 & 0.83 & 0.15 & -0.01 \\
\hline OCTTCI & 0.46 & 0.20 & 0.03 & 0.75 & 0.05 & 0.10 \\
\hline NOVTCI & 0.75 & -0.14 & 0.21 & 0.39 & 0.22 & 0.02 \\
\hline DECTCI & 0.76 & -0.29 & 0.18 & 0.19 & 0.00 & -0.12 \\
\hline Eig. & 10.63 & 4.78 & 3.49 & 1.35 & 0.98 & 0.64 \\
\hline Var. & 44.28 & 19.90 & 14.55 & 5.61 & 4.09 & 2.68 \\
\hline Varac. & 44.28 & 64.18 & 78.73 & 84.34 & 88.44 & 91.12 \\
\hline
\end{tabular}

nent with variance of $14.55 \%$ showed the influence of spring in both regions $\left(\mathrm{SST}>24.2^{\circ} \mathrm{C}\right.$ in $\mathrm{MB}$, and $20.3^{\circ} \mathrm{C}$ in $\mathrm{CI}$ ), April, and May in $\mathrm{MB}$, and March, April, May, and June in CI. The variance accumulated for these principal components was $78.73 \%$, and their coefficients were positives in all cases, and higher than the mean $\left(19.3^{\circ} \mathrm{C}\right)$. Thus, during autumn, winter and spring for both regions the variations in recruitment of Pacific sardine was related to warmer waters. The principal components 4, 5 and 6 showed a contribution in accumulated variance of $12.38 \%$, so their coefficients were not analysed.

The parameters of the multiple linear model that relate the principal components to $\alpha_{t}$ are shown in Table 3. The values of the principal components for each year allow one to estimate a new value of $\alpha_{t}$ as a function of the interannual variability of the SST. It was compared with the observed values of $\alpha_{t}\left(r^{2}=\right.$ $0.96, P<0.05$ ) (Fig. 2) in the Ricker model (expression 5). In this model, we determined $\alpha_{t}=3.38$ as the standard curve of stock recruitment relation in the Ricker model. Values of $\alpha_{t}>3.38$ showed high recruitment, greater than $25,000 \mathrm{t}$, and the low recruitment was obtained with values of $\alpha_{t}<3.38$, lower than $15,000 \mathrm{t}$. Two examples of this condition
TABLE 3. - Coefficients of the multiple linear model among $\alpha_{t}$ and principal components estimated.

\begin{tabular}{lrcc}
\hline Constant & Value & Standard Error & P-level \\
\hline $\mathrm{a}_{0}$ & 3.36 & 0.083 & 0.000 \\
$\mathrm{a}_{1}$ & -0.34 & 0.086 & 0.056 \\
$\mathrm{a}_{2}$ & -0.48 & 0.085 & 0.030 \\
$\mathrm{a}_{3}$ & 0.55 & 0.086 & 0.023 \\
$\mathrm{a}_{4}$ & 0.34 & 0.086 & 0.058 \\
$\mathrm{a}_{5}$ & -0.22 & 0.101 & 0.152 \\
$\mathrm{a}_{6}$ & 0.14 & 0.106 & 0.304 \\
\hline
\end{tabular}

are shown in Figure 3. Values of $\alpha_{t}=6.19$ (1992) were related to recruitment of $32,000 \mathrm{t}$, and $\alpha_{t}=1.98$ (1990) to recruitment of $16,000 \mathrm{t}$.

\section{DISCUSSION}

We have shown a relation between the variations of the coefficient $\alpha_{t}$ and the recruitment of $S$. caeruleus, but the explanation of this dependency is difficult to interpret. Lluch-Belda et al. $(1989,1991$, $1992 \mathrm{a}, \mathrm{b})$ showed that there is a relation between SST, abundance, distribution, and the possible relation of these to the recruitment of $S$. caeruleus, explaining an expansion and contraction pattern of 


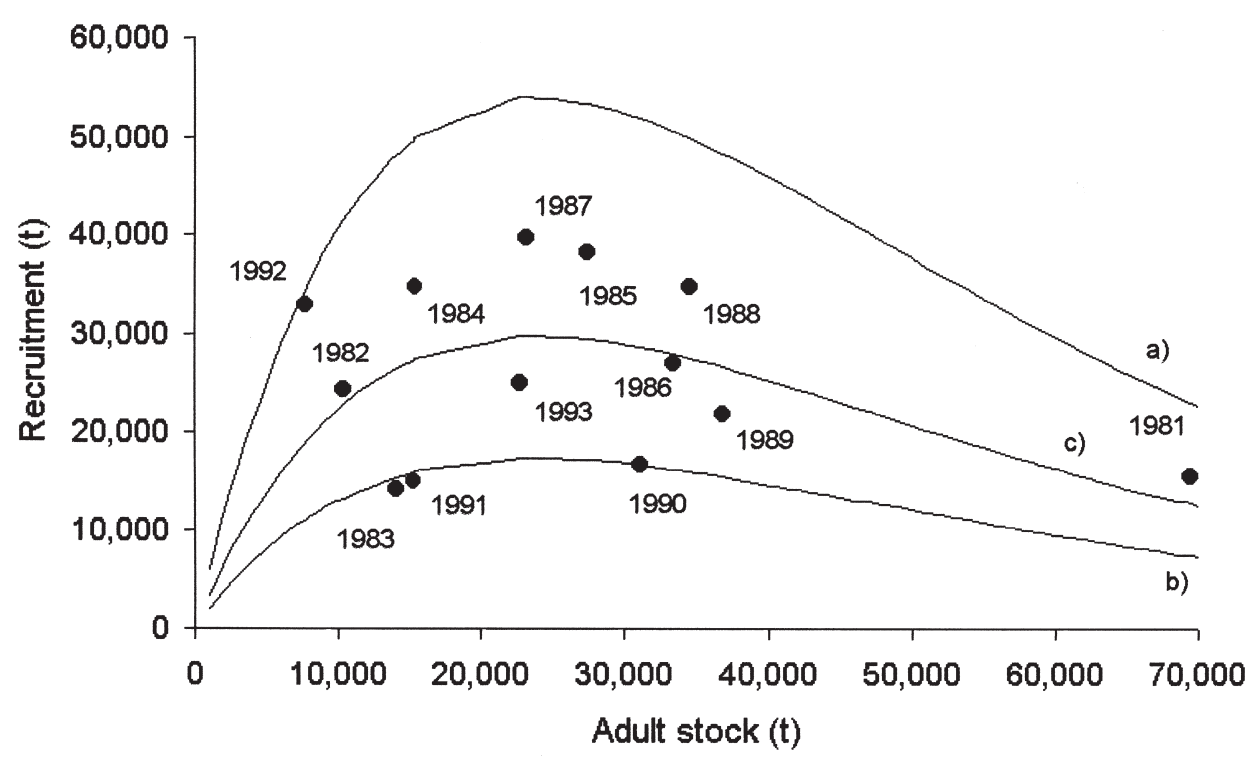

FIG. 3. - Ricker model estimated with two different conditions of the SST; a) 1992 was estimated with $\alpha=6.19$, b) 1990 was estimated with $\alpha=1.98$, and c) shows the Ricker model estimated with nonlinear fit.

the population in the California Current. Furthermore, Félix-Uraga et al. (1996) showed a local movement between Bahía Magdalena, Isla Cedros, and Ensenada associated with SST. Kawasaki (1983, 1992) proposed an ecological model of the interaction between the marine environment and the survival of the communities of phytoplankton and zooplankton. The changes in these communities directly affect the population of Pacific sardine. Among the variables, SST is important in the regulation of development, growth, and larval survival (RamírezSevilla et al., 1992; Bloomer et al., 1994), whereas in adults, the SST mainly modifies spawning through a change in the distribution of the spawning areas along the California Current (HernándezVázquez, 1994).

The analysis of the stock-recruitment relation with environmental variability has in some cases shown an understanding of the variability of the recruitment (Anthony and Fogarty, 1985; Clark, 1992; Hannah, 1993). However, the methods used are generalised models having an empirical approximation of the interpretation of the recruitment-environment relation. Roy et al. (1992) and Cury and Roy (1989), using simulation models, showed that the success of the recruitment is related to optimal environmental conditions. In this study, the influence of the variability of the SST has been defined in two different regions, describing the seasons with greater influence on the density-independent mortality of $S$. caeruleus. The combined effect of this variability in the marine environment may be explained by the presence of the events that cause fluctuation in the recruitment of $S$. caeruleus. Félix-Uraga et al. (1996) showed that periods of warming cause a redistribution of the population northward in the California Current, observing that a change of this type has the effect of low catch in the zone between Bahía Magdalena and Isla Cedros. Alvarado-Castillo et al. (1994) presented a theoretical model of annual distribution in the zone studied, showing that high SST values are associated with movement of the population of Pacific sardine northward of Bahía Magdalena during the summer and autumn, and that a low SST in winter and spring causes movement southward from Isla Cedros. This effect could be increased on a spatial and temporal scale by the influence of warming events (ENSO) (Wolf, 1992).

The Ricker model has a large compensatory density-dependent term, which implies that at high biomass, recruitment is low. We used an analytical approach to incorporate environmental effects into the stock recruitment model, and through this approach we have identified SST seasons that are important in determining recruitment for the Bahía Magdalena sardine population. An interesting observation is that the recruitment during 1981 was lower at a higher adult stock level (Fig. 3). In this year, we observed an overcompensation occurring when the recruitment decreases as the spawning stock increases (Quinn II and Deriso, 1999). In the Gulf of California, Mexico a strong overcompensation was observed when stock-recruitment data of Pacific sardine were analysed (Cisneros-Mata et al., 
1995). The mechanism off the southwest coast of the Baja California peninsula is that when cooling occurs, sardine spawning is restricted to Punta Eugenia and Bahía Magdalena, Mexico. However, if a warmer period is observed the spawning stock shows a change in distribution toward the north. The recruitment is thus based on the spawning temperature and modification in the adult stock distribution (Lluch-Belda et al., 1992a; Alvarado-Castillo et al., 1994).

The statistical evidence observed in $\alpha_{t}$ during autumn, winter, and spring in Bahía Magdalena, and Isla Cedros can be related to environmental variability of SST (temporal and spatial) on a local scale (Cohen et al., 1991). The changes in upwelling are principally seasonal, and the pattern is strong upwelling during winter and spring, and weak upwelling during summer and fall (Martínez et al., 2000). Associated with these oceanographic conditions, the species shows two spawning periods, the most important peak being observed during winter (January and February), with another small peak during early summer (July and August) (Torres-Villegas et al., 1995). Hernández-Vázquez (1994) concluded that Bahía Magdalena is an important spawning area, with high occurrence during winter months and June. The offshore occurrence of sardine eggs and larvae in Bahía Magdalena and Punta Eugenia (Isla Cedros region) showed high percentages of positive stations for sardine eggs in the first $20 \mathrm{n}$. mi. (from 1951 to 1989). Nonetheless, the Punta Eugenia region shows high values for all months except May and June. The maximum values of occurrence in the Punta Eugenia region (August-October) are much higher than those observed in Bahía Magdalena; the spawning zones are therefore well identified.

The results of this study indicate that temporal changes in sea surface temperature coincide with the most important spawning period of $S$. caeruleus, and if the success in survival of early stages is due to SST, then they are the ultimate regulators of year class strength of $S$. caeruleus. In this case, temperature can be related to deviations from the stockrecruitment relationship, explaining the apparent stochastic behavior and variance of the data (Morales-Bojórquez, 1999). Given the previous background, it is possible that the match-mismatch hypothesis (Cushing, 1982) provides an explanation for fluctuations in recruitment of S. caeruleus. Similarly, Lasker (1975) also concluded that survival rates of larval northern anchovy Engraulis mordax depend not so much on plankton density as on the timing and intensity of upwellings and the production cycle of larvae and their food supply. Evidences from other small pelagic fishes also indicated that hydrographic events were ultimate factors influencing larval mortality and recruitment. Although empirical support for the match-mismatch hypothesis based on statistical evidence alone may be questionable (Bakun y Parrish, 1980), the match-mismatch hypothesis can be further corroborated.

\section{ACKNOWLEDGEMENTS}

We thank Ellis Glazier, CIBNOR, S.C., for editing the English-language text, and Billy Ernst of the Fisheries Center at the University of Washington for help with the tuning of the VPA. We thank Sergio Hernández-Vázquez for providing the sea surface temperature data. Additional thanks are due to two anonymous reviewers for critically reviewing the manuscript and providing many helpful suggestions.

\section{REFERENCES}

Alvarado-Castillo, R.M., R. Félix-Uraga and R. Carmona. - 1994. Modelo de distribución anual de la subpoblación de Sardinops caeruleus en la costa oeste de la Península de Baja California. Mem. Annual Conference California Cooperative Oceanic Fisheries Investigations., p. v-14. Lake Tahoe, California.

Anthony, V.C. and M.J. Fogarty. - 1985. Environmental effects on recruitment, growth and vulnerability of Atlantic herring ( $\mathrm{Clu}$ pea harengus harengus) in the Gulf of Maine region. Can. J. Fish. Aquat. Sci., 42(Suppl. 1): 158-173.

Bakun, A. and R.H. Parrish. - 1980. Environmental inputs to fishery population models for eastern boundary current regions. In: Intergovernmental Oceanographic Commision, Workshop on the effects of environmental variation on the survival of larval pelagic fishes, pp. 67-104.

Baumgartner, T., A. Soutar and V. Ferreira-Bartrina. - 1992. Reconstruction of the history of Pacific sardine and northern anchovy populations over the past two millenia from sediments of the Santa Barbara basin, California. Calif. Coop. Oceanic Fish. Invest. Reports., 33: 24-40.

Bloomer, S.F., K.L. Cochrane and J.G. Field. - 1994. Towards predicting recruitment success of anchovy Engraulis capensis in the southern Benguela system using environmental variables: A rule-based model. South Afr. J. Mar. Sci., 14: 107-119.

Cisneros-Mata, M.A., T. Brey, A. Jarre-Teichman, W. García and G. Montemayor. - 1996. Redes de neuronas artificiales para el pronóstico de biomasa de sardina del Pacífico y de su medio ambiente. Ciencias Marinas., 22(4): 427-442.

Cisneros-Mata, M.A., M.O. Nevárez-Martínez and M.G. Hammann. -1995 . The rise and fall of the Pacific sardine, Sardinops sagax caeruleus Girard, in the Gulf of California, México. Calif. Coop. Oceanic Fish. Invest. Reports., 36: 136-143.

Clark, R.A. - 1992. Influence of stream flows and stock size on recruitment of Artic grayling (Thymallus arcticus) in the Chena river, Alaska. Can. J. Fish. Aquat. Sci., 49: 1027-1034.

Cohen, E.B., D.G. Mountain and R. O'boyle. - 1991. Local-scale versus large-scale factors affecting recruitment. Can. J. Fish. Aquat. Sci., 48: 1003-1006.

Cury, P. and C. Roy. - 1989. Optimal environmental window and pelagic fish recruitment succes in upwelling areas. Can. J. Fish. Aquat. Sci., 46: 670-680.

Cushing, D.H. - 1982. Climate and fisheries. Academic Press, New York. 
Deriso, R.B., T.J. Quinn II and P.R. Neal. - 1985. Catch-age analysis with auxiliary information. Can. J. Fish. Aquat. Sci., 42: 815-824.

Doi, T. - 1973. A theoretical treatment of the reproductive relationship between recruitment and adult stock. Rapp. P.-v Reun. Cons. Int. Explor. Mer., 341-349.

Félix-Uraga, R., R. M. Alvarado-Castillo and R. Carmona-Piña. 1996. The sardine fishery along the Western coast of Baja California, 1981 to 1994. Calif. Coop. Oceanic Fish. Invest. Reports., 37: 188-192.

Gardiner, R. and T. Shackley. - 1991. Stock and recruitment and inversely density-dependent growth of salmon, Salmo salar L., in a Scottish stream. J. Fish Biol., 38: 691-696.

Hannah, R.W. - 1993. Influence of environmental variation and spawning stock levels on recruitment of ocean shrimp (Pandalus jordani). Can. J. Fish. Aquat. Sci., 50: 612-622.

Harris, J.G.K. - 1975. The effect of density-dependent mortality on the shape of the stock and recruitment curve. J. Cons. int. Explor. Mer., 36 (2): 144-149.

Hemingway, G. - 1979. A description of the California Current ecosystem by factor analysis. Calif. Coop. Oceanic Fish. Invest. Reports., 20: 164-183.

Hernández-Vázquez, S. - 1994. Distribution of eggs and larvae from sardine and anchovy off California and Baja California, 19511989. Calif. Coop. Oceanic Fish. Invest. Reports., 35: 94-107.

Hilborn, R. and C. Walters. - 1992. Quantitative fisheries stock assessment. Choice, dynamics and uncertainty. Chapman-Hall. New York.

Huato-Soberanis, L. and D. Lluch-Belda. - 1987. Mesoscale cycles in the series of environmental indices related to the sardine fishery in the Gulf of California. Calif. Coop. Oceanic Fish. Invest. Reports., 28: 128-134.

Illes, T.D. - 1973. Interaction of environment and parent stock size in determining recruitment in the Pacific sardine as revealed by analysis of density-dependent 0-group growth. Rapp. P.-V. Reun. Cons. Int. Explor. Mer., 164: 228-240.

Jacobson, L.D. and A.D. MacCall. - 1995. Stock-recruitment models for Pacific sardine (Sardinops sagax). Can. J. Fish. Aquat. Sci., 52: 566-577.

Kawasaki, T. - 1983. Why do some fishes have wide fluctuations in their numbers? - Biological basis of fluctuation from the viewpoint of evolutionary ecology. In: G. D. Sharp and J. Csirke (eds.), Proceedings of the Expert Consultation to Examine Changes in Abundance and Species Composition of Neritic Fish Resources. FAO Fish. Rep., 291(3): 1065-1080.

Kawasaki, T. - 1992. Mechanisms governing fluctuations in pelagic fish populations. South Afr. J. Mar. Sci., 12: 873-879.

Krzanowski, K.J. - 1993. Principles of multivariate analysis. A user's perspective. Sciences Publications. Oxford.

Lasker, R. - 1975. Field criteria for survival of anchovy larvae: the relation between inshore chlorophyll maximum layers and successful first feeding. Fish. Bull., 73: 453-462.

Lluch-Belda, D., R.J.M. Crawford, T. Kawasaki, A.D. MacCall, R.H. Parrish, R.A. Schwartzlose and P.E. Smith. - 1989. World-wide fluctuations of sardine and anchovy stocks: the regime problem., South Afr. J. Mar. Sci., 8: 195-205.

Lluch-Belda, D., D.B. Lluch-Cota, S. Hernández-Vázquez, C.A. Salinas-Zavala and R.A. Schwartzlose. - 1991. Sardine and anchovy spawning as related to temperature and upwelling in the California Current system. Calif. Coop. Oceanic Fish. Invest. Reports., 32: 105-111.

Lluch-Belda, D., S. Hernández-Vázquez, D.B. Lluch-Cota, C.A. Salinas-Zavala and R.A. Schwartzlose. - 1992a. The recovery of the California sardine as related to global change. Calif. Coop. Oceanic Fish. Invest. Reports., 33: 50-59.

Lluch-Belda, D., D.B. Lluch-Cota, S. Hernández-Vázquez and C.A. Salinas-Zavala. - 1992b. Sardine population expansion in eastern boundary systems of the Pacific Ocean as related to sea surface temperature., South Afr. J. Mar. Sci., 12: 147-155.

Manly, B.F.J. - 1994. Multivariate statistical methods. Chapman and Hall. London.

Mardia, K.V., J.T. Kent and J.M. Bibby. - 1989. Multivariate analysis. Academic Press. London.

Marr, J.C. - 1960. The causes of major variations in the catch of the Pacific sardine Sardinops caerulea (Girard). In: H. Rosa and G. Murphy (eds.), Proceedings of the world scientific meeting on the biology of sardines and related species., (3): 667-791. FAO, Rome, Italy.

Martínez, G., O. Zaitsev, F. Salinas and A. Gallegos. - 2000. Segmentación de temperatura superficial del mar por crecimiento de regiones en imágenes NOAA-AVHRR. In: H. Hernández (ed.), Congreso Internacional de Computación 2000. pp. 336344. Instituto Politécnico Nacional, CIC, México.

Milstein, A. - 1993. Factor and canonical analyses: basic concepts, data requirements and recommended procedures. In: M. Prein, G. Hulata and D. Pauly (eds.), Multivariate methods in aquaculture research: case studies of tilapias in experimental and commercial systems, pp. 24-31. ICLARM Stud. Rev.

Morales-Bojórquez, E. - 1999. Análisis del error de proceso y de observación en la estimación del reclutamiento de la sardina del Pacífico (Sardinops sagax caeruleus Girard), en la costa suroeste de la Península de Baja California, México. Ciencias Marinas., 25(4): 597-608.

Morrison, D. - 1990. Multivariate statistical methods. McGrawHill. New York.

Murphy, G.I. - 1960. Oceanography and variations in the Pacific sardine population. Calif. Coop. Oceanic Fish. Invest. Reports., 8: $55-64$.

Ortega-García, S. and V.M. Gómez-Muñoz. -1992. Standardization of fishing effort using principal component analysis of vessel characteristics: the Mexican tuna purse-seiners. Sci. Mar., 56(1): 17-20

Pielou, E.C. - 1984. The interpretation of ecological data. A primer on classification and ordination. John Wiley and Sons. New York.

Pope, J.G. - 1972. An investigation of the accuracy of virtual population analysis using cohort analysis. Int. Comm. Northwest Atlantic Fish. Res. Bull., 9: 65-74.

Quinn II, T. J. and R. B. Deriso. - 1999. Quantitative fish dynamics. Oxford University Press. New York.

Ramírez-Sevilla, R, R. Martínez-Pecero, E. Mátuz-Nivón, J.L. Ortiz-Galindo and M. Contreras-Olguín. - 1992. Tasas de desarrollo de Sardinops sagax caerulea. Invest. Mar., 7(2): 123-125.

Ricker, W.E. - 1975. Computation and interpretation of biological statistics of fish populations. Bull. Fish. Res. Board Canada., 191: $382 \mathrm{p}$.

Roy, C., P. Cury and S. Kifani. - 1992. Pelagic fish recruitment success and reproductive strategy in upwelling areas: environmental compromises. South Afr. J. Mar. Sci., 12: 135-146.

Roy, C. and R. Mendelssohn. - 1994. COADS on CD-ROM volume 5: Eastern Pacific Ocean. ORSTROM and NOAA. Climate and Eastern Ocean System (CEOS) Program.

Smith, P.E., N. Chyan-Huei Lo and J.L. Butler. - 1992. Life-stage duration and survival parameters as related to interdecadal population variability in Pacific sardine. Calif. Coop. Oceanic Fish. Invest. Reports., 33: 41-49.

Sokal, R.R. and F. Rholf. - 1981. Biometry. W. H. Freeman and Company. New York.

Tabachnich, B.G. and L.S. Fidell. - 1989. Using multivariate statistics. Harper Collins. New York.

Tang, Q. - 1985. Modification of the Ricker stock recruitment model to account for environmentally induced variation in recruitment with particular reference to the blue crab fishery in Chesapeake Bay. Fish. Res., 3: 13-21.

Tang, Q., J. Deng and J. Zhu. - 1989. A family of Ricker SSR curves of the prawn (Penaeus orientalis) under different environmental conditions and its enhancement potential in the Bohai Sea. In: R. J. Beamish and G. A. McFarlane (eds.), Effects of ocean variability on recruitment and an evaluation of parameters used in stock assessment models. Can. J. Fish. Aquat. Sci., 108: 335-339.

Torres-Villegas, J.R., R.I. Ochoa-Baez, L. Perezgomez and G. García-Melgar. - 1995. Comparison of seasonal variability in the reproduction of Pacific sardine (Sardinops sagax) from Baja California Sur, México, in the years 1982-1992. Sci. Mar., 59(3-4): 255-264.

Wolf, P. - 1992. Recovery of the Pacific sardine and the California sardine fishery. Calif. Coop. Oceanic Fish. Invest. Reports., 33: 76-86.

Scient. ed.: W. Norbis 